\title{
The Role of Epigallocathecin-3-gallate as an Antioxidant After Dental Bleaching on Shear Bond Strength of Composite Resin Restoration
}

\author{
Syarifah Nadhira Assyafira Al-Habsyi ${ }^{1}$, Kun Ismiyatin ${ }^{2}$, Galih Sampoerna ${ }^{3}$ \\ ${ }^{1}$ Undergraduate of Dental Medicine, Faculty of Dental Medicine, Universitas Airlangga, Surabaya-Indonesia \\ ${ }^{2,3}$ Department of Conservative Dentistry, Faculty of Dental Medicine, Universitas Airlangga, Surabaya-Indonesia
}

\begin{abstract}
Background: Tooth discoloration can be treated with dental bleaching using Hydrogen peroxide $\left(\mathrm{H}_{2} \mathrm{O}_{2}\right)$. Dental bleaching may interfere with the shear bond strength of composite resins because the remaining free radicals can affect bonding polymerization. Epigallocatcehin-3-gallate (EGCG) as an antioxidant can neutralize the free radicals produced during bleaching process. Purpose: Analyze the role of EGCG antioxidants in increasing the shear bond strength of composite resin after bleaching.. Review: Of the seven journals included in this literature review, six journals reported significant difference, and one journal noted no significant difference in the shear bond strength of composite resin following the EGCG application. Conclusion: The use of EGCG can increase the shear bond strength value of post-bleaching composite resin restorations.
\end{abstract}

Keywords: Epigallocathecin gallate; Dental Bleaching; Composite Resins; Shear Bond Strength; Antioxidants

Correspondence: Kun Ismiyatin, Department of Conservative Dentistry, Faculty of Dental Medicine, Universitas Airlangga, Jl. Mayjen. Prof. Dr. Moestopo No.47 Surabaya, 60132 Indonesia. Email: kun-is@fkg.unair.ac.id

\section{INTRODUCTION}

Tooth discoloration problems as well as the aesthetic demand for a whiter smile from patients can be treated with a procedure in dentistry called dental bleaching. The bleaching agent that is often used in the market is $\mathrm{H}_{2} \mathrm{O}_{2}$. The mechanism of tooth whitening by $\mathrm{H}_{2} \mathrm{O}_{2}$ in is by the production reactive free radicals which will oxidize organic compounds from chromophores in cases of teeth with discoloration. ${ }^{1}$

Tooth whitening reaction with $\mathrm{H}_{2} \mathrm{O}_{2}$ will leave residual free radicals, Perhydroxyl $\left(\mathrm{HO}_{2}\right)$ which is a strong free radical and Onasen $\left(\mathrm{O}_{-}\right)$which is a weak free radical. In some cases, after the bleaching process, composite resin restoration is required, the residual free radicals will disrupt the polymerization of composite resin. ${ }^{2}$ The remaining free radicals from the bleaching material will prevent the infiltration of the bonding material into the tooth structure so that after bleaching, the shear bond strength of the restoration will have a low value. ${ }^{3}$

The solution that is often used in this problem is to delay composite resin restoration for 7-14 days after bleaching. One alternative procedure that can be done to reduce the time interval between the bleaching procedure and composite resin is the application of antioxidants. Antioxidants that are often used in neutralizing free radicals are Ascorbic acid (vitamin C) and Tocopherol (vitamin E). Vitamin C has a
$\mathrm{pH}$ of 1.8 (very acidic) so it can reduce enamel hardness, cause the accumulation of Streptococcus mutans bacteria on the enamel, and a short duration of action. ${ }^{4}$ Vitamin $\mathrm{E}$ is insoluble in water. ${ }^{5}$ Green tea Epigallocathecin gallate (EGCG) extract is a natural antioxidant that can be used as an alternative substance of choice, this is because the advantages of EGCG as a natural ingredient were that the side effects are minimal, long working duration, and a relatively low cost. ${ }^{6}$ According to a University of Kansas study, EGCG has antioxidant properties 100 times more effective than vitamin $\mathrm{C}$ and 25 times more effective than vitamin $\mathrm{E}$. The purpose of this literature review is to analyze the role of EGCG antioxidants in increasing the shear bond strength of post-bleaching composite resin restoration.

\section{REVIEW}

Tooth whitening or more popularly known as bleaching is the act of chemically whitening teeth using a strong oxidizing agent called $\mathrm{H}_{2} \mathrm{O}_{2}$. In dentistry, there are two ways to do bleaching, external bleaching which is performed on vital teeth and internal bleaching on non-vital teeth. ${ }^{7,8} \mathrm{H}_{2} \mathrm{O}_{2}$ as a whitening agent can be applied by dentists in clinical practice (in-office bleaching) with a concentration of 30$35 \%$ or by patients themselves at home under a doctor's supervision (home bleaching) with a concentration of 10- 
$15 \% .{ }^{9}$ In dentistry, the most commonly used tooth whitening agent is $5-35 \% \mathrm{H}_{2} \mathrm{O}_{2}$ because $\mathrm{H}_{2} \mathrm{O}_{2}$ penetrates faster than carbamide peroxide and sodium perborate. ${ }^{1}$

The mechanism of tooth whitening consists of three stages, the first stage is the infiltration of the whitening agent in to the tooth structure, the interaction between the whitening agent and chromogen, and last one is the change of color in tooth surface. After the $\mathrm{H}_{2} \mathrm{O}_{2}$ penetrates into the dentin, there will be a reaction between $\mathrm{H}_{2} \mathrm{O}_{2}$ and the chromogen that occur in the tooth structure. When $\mathrm{H}_{2} \mathrm{O}_{2}$ comes into contact with the tooth surface, an oxidation process will occur which is part of the redox reaction. ${ }^{10}$ $\mathrm{H}_{2} \mathrm{O}_{2}$ undergoes decomposition into hydrogen cations $(\mathrm{H}$ $\left.{ }^{+}\right)$and perhdroxyl anions $\left(\mathrm{HO}_{2}^{-}\right)$. Perhydroxyl anion $\left(\mathrm{HO}_{2}^{-}\right)$ will take other peroxide molecules to form hydroxyl free radicals $(\mathrm{OH})$, and onasen $\left(\mathrm{O}^{-}\right)$. Free radicals formed from the $\mathrm{H}_{2} \mathrm{O}_{2}$ redox reaction will release unpaired electrons which will bind to the chromogen molecule then breaks the chromogen bond, which was a complex bond to a simpler one so that a change to lighter color will occur. ${ }^{11}$

Antioxidants are stable molecules that can donate electrons to reactive free radicals therefore they can inhibit the oxidation process by forming relatively stable unreactive free radicals. Due to this mechanism, antioxidants can protect cells from the damaging effects of reactive oxygen free radicals. ${ }^{12,13}$ In the advancement of technological developments, there are many natural ingredients that have antioxidant properties to reduce free radicals. One natural ingredient which has had a lot of research on its antioxidant abilities is EGCG. ${ }^{14}$ EGCG has antioxidant, anti-inflammatory, anti-carcinogenic, and antimicrobial properties. The antioxidant effect of these catechins is based on the chemical structure, the combination of aromatic rings and hydroxyl groups that compose them so that they can bind and neutralize free radicals. ${ }^{15}$

In a study by Lan-Sook et al., regarding the quantitative analysis of catechin components in green tea using the DPPH, FRAP, and ABTS methods, EGCG was shown to have the highest results. ${ }^{16}$ Directly, the antioxidant effect of EGCG is by transfer of hydrogen atoms or single electrons which involve the hydroxyl group that belongs to EGCG. ${ }^{17}$ EGCG compounds also have the ability to chelate metal ions and inhibit the production of Reactive Oxygen Species (ROS) by inhibiting xanthine oxidase enzymes. ${ }^{18}$

A parameter that is often used in laboratories to measure the adhesion of restorative materials to tooth structures is the shear bond strength test. Shear bond strength is the maximum resistance of a material to withstand loads that cause shear motion on the material before being released. ${ }^{19}$ The binding strength of a fixing material to the hard tooth tissue can be done by pushing the material against the tooth surface, the value of the shear bond strength obtained will provide an illustration of how the material adheres to the hard tissue of the tooth. ${ }^{20}$

The measurement procedure uses the universal testing machine. The subject is placed on the table and fixed so that it cannot move. Previously, on the table was already a load of $50 \mathrm{Kgf}$ which would move down to shift the teeth that had been restored by composite resin with a crosshead speed of $0.50 \mathrm{~mm} /$ minute, the monitor screen is connected to the universal testing machine which would show a number indicating the shear force used in shifting the composite resin until it is released from the dentin surface, then the amount of $\mathrm{F}$ is recorded on the machine screen to calculate the shear bond strength value. ${ }^{21}$

\section{DISCUSSION}

After the bleaching process, remaining free radicals from $\mathrm{H}_{2} \mathrm{O}_{2}$ will be formed which will inhibit the polymerization of the composite resin. ${ }^{22}$ The residual free radicals in the tooth structure after bleaching with $\mathrm{H}_{2} \mathrm{O}_{2}$ can react with free radicals from the bonding material which will interfere with the propagation of vinyl during light-cured causing premature termination of the polymer chain. The decreased strength of the bonding material will interfere with the penetration process of the bonding material through the dentin tubules therefore the bond between the resin-dentin (hema-collagen) cannot be formed completely, thus a regular hybrid layer will not be formed well. ${ }^{2}$ Inadequate polymerization of composite resin causes the adhesive system of the bonding between resin and teeth to become weak which will cause the shear bond strength value of post-bleaching composite restorations to be low. ${ }^{23}$

Khamverdi et al., evaluated the effect of herbal antioxidants on shear bond strength of composite resin on bleached enamel. Results showed that the average shear bond strength in group control (no bleaching) was $22.61 \pm$ 3.29 $\mathrm{MPa}$ while in group 2 (bleaching) was only $5.78 \pm 1.80$ $\mathrm{MPa}$. In group 3 (bleaching + EGCG) showed significant difference in bond strength which was $20.07+1.45 \mathrm{MPa} .{ }^{24} \mathrm{It}$ can be concluded that tooth bleaching results in a significant reduction in bond strength.

Diatri and Andina evaluated the effect of antioxidants on the shear bond strength of composite resin to enamel following extra-coronal bleaching which showed that teeth with composite resin restorations without bleaching has the highest shear bond strength value: $19.43 \mathrm{MPa}$, while teeth with direct composite resin restorations after bleaching has the lowest shear bond strength value: 9.50 MPa. After applying EGCG to the bleached teeth and immediately restoring the composite resin, the shear bond strength value increased to $15.55 \mathrm{MPa}^{3}$

Sharafeddin et al., assessed the effect of green tea extract as antioxidant on the shear bond strength of resin composite to in-office and home-bleached enamel. According to their findings, teeth with post-bleaching composite resin restorations has the lowest shear bond strength value: 10.52 $\mathrm{MPa}$, meanwhile after EGCG was applied to bleached enamel and composite resin restoration was immediately carried out, the value of shear bond strength increased to 16.76 $\mathrm{MPa}^{25}$

Dhingra et al., compared the effect of using various antioxidant solutions on shear bond strength of composite resin to bleached enamel. Results showed that in group 
I as positive control: composite resin restoration without bleaching has shear bond strength value of $19.30 \pm 1.81$ $\mathrm{MPa}$, while in group II as negative control: composite resin restoration after bleaching decreased the shear bond strength value significantly to $7.83 \pm 2.21 \mathrm{MPa}$. After applying EGCG to bleached enamel and immediately performing composite resin restoration, the value of the shear bond strength increased to $13.72 \pm 4.16 \mathrm{MPa} .^{5}$

Khamverdi et al., evaluated the effect of Epigallocatechin gallate on the shear bond strength of composite resin to bleached enamel. Result showed in group 1 control (no bleaching) that the average shear bond strength $22.61 \pm 3.29$ $\mathrm{MPa}$, while for teeth that were bleached and then proceeded with composite restoration, the shear bond strength value decreased by $5.18 \pm 3.28 \mathrm{MPa}$. After applying EGCG, the shear bond strength increased to $12.12 \pm 1.22 \mathrm{MPa}{ }^{26}$

Guriea \& Bharath compared the effect of two nonenzymatic antioxidants on the shear bond strength of resin based composite restoration to office bleached enamel. It was shown that group 1 control (no bleaching) has the highest shear bond strength value of $25.55 \mathrm{MPa}$, while teeth with direct composite resin restorations after bleaching has the lowest shear bond strength value of $12.14 \mathrm{MPa}$. After applying EGCG to bleached enamel and performing composite resin restoration, the value of shear bond strength increased to $19.72 \mathrm{MPa}^{27}$

Jain et al., assessed the effect of herbal antioxidant extract on the bonding of composite resin to bleached enamel. It was shown that the group without bleaching had the highest shear bond strength value: $83.8 \pm 5.21$ $\mathrm{MPa}$, while teeth with direct composite resin restorations after bleaching decreased to $56.12 \pm 3.4 \mathrm{MPa}$. Then, after applying EGCG to bleached enamel and immediately performing composite resin restoration did not show any significant increase in shear bond strength value, the result was only $57.76 \pm 4.41 \mathrm{MPa}^{28}$

After the application of EGCG, the shear bond strength values of the six experiments all showed a significant increase, this was due to the presence of a hydroxyl group $(\mathrm{OH})$ from ring $\mathrm{B}$ which is in the chemical structure of EGCG. The direct mechanism of action of EGCG as an antioxidant is by donating a hydrogen atom $(\mathrm{H})$ and transferring a single electron by pairing it with free electrons belonging to free radicals from $\mathrm{H}_{2} \mathrm{O}_{2} \cdot{ }^{29}$ Effective antioxidant compounds are those that have more than one active structure $(\mathrm{OH})$ which have the ability to form intramolecular hydrogen bonding (iHB). ${ }^{30}$ The reaction of the hydrogen atom donor mechanism is as follows, one $\mathrm{H}$ atom from the flavonoid EGCG (Fl-OH) is transferred to Perhydroxyl $\left(\mathrm{HO}_{2}\right)$ produced by $\mathrm{H}_{2} \mathrm{O}_{2}$ to form phenoxyl radicals $(\mathrm{HOOH}$ + Fl-O) which are more stable than Perhydroxyl. In this process, there is also an electron transfer, $\mathrm{HO}_{2}$ which is a free radical that requires one electron to stabilize itself by binding to the $\mathrm{H}$ in the flavonoid hydroxyl group, the flavonoids lose one electron to form oxygen radicals. ${ }^{31}$

In the six articles above the value of the shear bond strength of composite resin restoration to bleached enamel after application of EGCG have various results. The most effective was in the study by Khamverdi et al., which showed SBS $20.07 \pm 1.45 \mathrm{Mpa}$, EGCG is used in the form of a $1000 \mu \mathrm{mol}$ solution which is applied with a microbrush for 10 minutes and re-applied every 1 minute on the tooth surface. ${ }^{24}$ Second, Guria \& Bharath with the results of SBS 19.72 MPa, the author used EGCG 5\% which was applied using a heated excavator with application method as often as possible for 10 minutes to prevent the solution from drying out. ${ }^{27}$ Third, Sharafeddin et al., with the results of SBS $16.76 \mathrm{MPa}$, the author used EGCG 5\% which was applied for 10 minutes. ${ }^{25}$ Fourth, Nari Ratih \& Widyastuti with the results of SBS $15.55 \mathrm{MPa}$, the author used $10 \%$ EGCG which was applied using a syringe in a size of 0.02 $\mathrm{ml} \&$ smeared evenly on the enamel using a sponge pellet every 1 minute in the period of 10 minutes. ${ }^{3}$. Then, Dhingra et al., with the results of SBS $13.72 \pm 4.16 \mathrm{Mpa}$, the authors used 5\% EGCG solution which was applied using a syringe at a speed of $1 \mathrm{ml} /$ minute for 10 minutes. ${ }^{5}$ The lowest SBS value was found in Khamverdi et al: $12.12 \pm 1.22 \mathrm{MPa}$, the sample was immersed in a $1000 \mu \mathrm{mol}$ EGCG solution for 10 minutes. ${ }^{26}$ The various concentrations of EGCG: $5 \%$, $10 \%$, and $1000 \mu \mathrm{mol}$, have been proven to be successful in increasing the shear bond strength of composite resin after bleaching. The duration of EGCG application from the six journals above used the minimum duration for EGCG to give its antioxidant effect according to the research of Khamverdi et al., which is 10 minutes in accordance with the theory from previous studies. ${ }^{26}$

Jain et al., showed that EGCG did not significantly increase the value of the shear bond strength of composite restorations after bleaching. This may occur due to limitations in the study, differences in concentration, and duration of EGCG application. In addition, an insignificant increase could also occur because the duration of the EGCG application that was used was only 8 minutes. ${ }^{28}$ According to Khamverdi et al., the duration of EGCG application for 10 minutes is the minimum time for this material to provide an antioxidant effect. ${ }^{26}$ The most visible difference in shear bond strength numbers is in Jain et al., with a range of values from 50-80 MPa while the other six journals are only in the range of 10-20 $\mathrm{MPa}$, the difference in the resulting shear bond strength values occur because of the universal testing machine protocol for measuring shear bond strength are different in every experiment.

The antioxidant activity of EGCG can reduce the side effects of bleaching by neutralizing the free radicals produced by $\mathrm{H}_{2} \mathrm{O}_{2}$ so that it can prevent interference with the polymerization of composite resin on teeth so composite resin restoration can be done as soon as possible after bleaching. ${ }^{32}$

\section{REFERENCES}

1. Pandey SH, Patni PM, Jain P, Chaturvedi A. Management of intrinsic discoloration using walking bleach technique in maxillary central incisors. Clujul Med. 2018;91(2):229-33.

2. Nofika R, Nugraheni T, Hadriyanto W. Pengaruh aplikasi natrium askorbat $10 \%$ dan $35 \%$ terhadap panjang resin tag 
pada gigi pasca bleaching intrakoronal dengan hidrogen peroksida 35\%. Vol. 9. 2018;9(2):280-286.

3. Nari-Ratih D, Widyastuti A. Effect of antioxidants on the shear bond strength of composite resin to enamel following extra-coronal bleaching. J Clin Exp Dent. 2019;11(2): 12632.

4. Rana R, Kaushik M, Sharma R, Reddy P, Mehra N. Comparative Evaluation of Effects of Natural Antioxidants on the Shear Bond Strength of Composite Resin to Bleached Enamel. Indian J Dent Res. 2017;29(2):212-6.

5. Dhingra A, Gupta AK, Minocha A, Sen N. Comparative Evaluation of Immediate Bond Strength. 2017;5(2321):84-9.

6. Al Hassani AA. Effect of Delayed Bonding and Different Antioxidants on Composite Restoration Microleakage of Internally Bleached Teeth. Adv Dent Oral Heal. 2018;9(3):88-93.

7. Carey CM. Tooth whitening: What we now know. J Evid Based Dent Pract. 2014;14(SUPPL.):70-6.

8. Rokaya ME, Beshr K, Mahram AH, Pedir SS, Baroudi K. Evaluation of Extraradicular Diffusion of Hydrogen Peroxide during Intracoronal Bleaching Using Different Bleaching Agents. Int J Dent. 2015.

9. De Menezes RP, Silva PD, Leal PC, Faria-e-Silva AL. Impact of $35 \%$ hydrogen peroxide on color and translucency changes in enamel and dentin. Braz Dent J. 2018;29(1):88-92.

10. Kwon SR, Wertz PW. Review of the mechanism of tooth whitening. J Esthet Restor Dent. 2015;27(5):240-57.

11. Young N, Fairley P, Mohan V, Jumeaux C. A study of hydrogen peroxide chemistry and photochemistry in tea stain solution with relevance to clinical tooth whitening. J Dent. 2012;40:e11-6.

12. Anuj Y, Rewa K, Ashwani Y, J.P. M, Seweta S, Shashi P. Antioxidants and its functions in human body. Res Environ Life Sci. 2016;9(11):1328-31.

13. Atta EM, Mohamed NH, Abdelgawad AAM. Antioxidants: an Overview on the Natural and Synthetic Types. Eur Chem Bull. 2017;6(8):365.

14. He J, Xu L, Yang L, Wang X. Epigallocatechin gallate is the most effective catechin against antioxidant stress via hydrogen peroxide and radical scavenging activity. Med Sci Monit. 2018;24:8198-206.

15. Ozelin AA, Guiraldo RD, De Carvalho RV, Lopes MB, Berger SB. Effects of green Tea application time on bond strength after Enamel Bleaching. Braz Dent J. 2014;25(5):399-403.

16. Lee LS, Kim SH, Kim YB, Kim YC. Quantitative analysis of major constituents in green tea with different plucking periods and their antioxidant activity. Molecules. 2014;19(7):917386.

17. Khamverdi Z. The Beneficial Effects of Green Tea in Oral Health and Dentistry. Biomed J Sci Tech Res. 2019;19(4):14460-3.

18. Legeay S, Rodier M, Fillon L, Faure S, Clere N.
Epigallocatechin gallate: A review of its beneficial properties to prevent metabolic syndrome. Nutrients. 2015;7(7):544368.

19. Susra W, Nur DL, Puspita S. Perbedaan Kekuatan Geser dan Kekuatan Tarik pada Restorasi Resin Komposit Mi- crohybrid dengan Bonding Generasi V dan Bonding Generasi VII . Ijd. 2013;02(02):68-75.

20. Faltermeier A, Roemer P, Reicheneder C, Proff P, Klinke T. The Influence of Surface Conditioning of Ceramic Restorations before Metal Bracket Bonding. Mater Sci Appl. 2012;03(01):1-5.

21. Lijaya VA, Santosa P, Hs D, Studi P, Konservasi I, Pendidikan P, et al. Perbedaan Kekuatan Geser Perlekatan Resin Komposit pada Dentin Menggunakan Bonding Total Etch dan Self Etch dengan dan Tanpa Aplikas Klorheksidin Diglukonat. KedGi J. 2013;Vol. 4, No:156-62.

22. Alqahtani MQ. Tooth-bleaching procedures and their controversial effects: A literature review. Saudi Dent J. 2014;26(2):33-46.

23. Guria A, M.J B. An in vitro comparative study evaluating the effect of two non- enzymatic antioxidants on shear bond strength of resin based. 2020;7(9):363-8.

24. Khamverdi Z, Khadem P, Soltanian A, Azizi M. In vitro Evaluation of the Effect of Herbal Antioxidants on Shear Bond Strength of Composite Resin to Bleached Enamel. J Dent Univ Med Sci. 2016;13(4):244-51.

25. F S, F F, B A, A A. Effect of Green Tea Extract as Antioxidant on Shear Bond Strength of Resin Composite to in-Office and Home-Bleached Enamel. J Dent Biomater. 2016;3(3):26975.

26. Khamverdi Z. Effect of Epigallocatechin Gallate on shear bond strength of composite resin to bleached enamel : an in vitro study. 2013;7658:241-7.

27. Guria A, M.J B. an in Vitro Comparative Study Evaluating the Effect of Two Non- Enzymatic Antioxidants on Shear Bond Strength of Resin Based. 2020;7(9):363-8.

28. Jain S, Gundappa M, Rani A, Agarwal A. Effect of Herbal Antioxidant Extract on Bonding Of Composite Resin to Bleached Enamel. TMU J Dent. 2017;4(4):128-31.

29. Laden Güleç Alagöz, Karadağlioğlu Öİ, Ulusoy N. Antioxidants used in Restorative Dentistry. Cyprus J Med Sci. 2019;4(2):141-5.

30. Bendary E, Francis RR, Ali HMG, Sarwat MI, El Hady S. Antioxidant and structure-activity relationships (SARs) of some phenolic and anilines compounds. Ann Agric Sci. 2013;58(2):173-81.

31. Chen X, Deng Z, Zhang C, Zheng S, Pan Y, Wang H, et al. Is antioxidant activity of flavonoids mainly through the hydrogen-atom transfer mechanism? Food Res Int . 2018.

32. Souza-Gabriel AE, Sousa-Neto MD, Scatolin RS, Corona SAM. Durability of resin on bleached dentin treated with antioxidant solutions or lasers. J Mech Behav Biomed Mater. $2020 ; 104$ 